\title{
Preventive Actions in Pressure Ulcer Development in Intensive Care Units
}

Belarmino Santos de Sousa Júnior ${ }^{1}$, Fernando Hiago da Silva Duarte ${ }^{2}$, Amanda Nayara Rodrigues Pereira ${ }^{3}$, Ana Elza Oliveira de Mendonça ${ }^{4}$, Gilson de Vasconcelos Torres ${ }^{5}$, Daniele Vieira Dantas ${ }^{5}$, Rodrigo Assis Neves Dantas ${ }^{5}$, Eurides Araujo Bezerra de Macedo 5

\section{Abstract}

Introduction: Preventive care of Pressure Ulcers have been increasingly enhanced, especially in the care of critically ill patients because they are exposed to intrinsic and extrinsic risk factors to develop them.

Objective: To show the contributions of scientific productions for the Prevention of Pressure Ulcers in Intensive Care Units.

Methods: Study of an integrative literature review held in April 2016. For the survey of the articles discussing the preventive action of pressure ulcers in critically ill patients, electronic searches were carried out in LILACS, SCIELO, and BDENF.

Results: The sample consisted of nine studies that allow the preparation of a summary of care, education, and management, fundamental actions for a culture of prevention injuries.

Conclusion: The study allowed summarizing the main care to guide the clinical practice of nurses in the daily care to critical patients.

\section{Keywords}

Prevention; Pressure Ulcer; Nursing; Intensive Care Unit.
1 Academic nursing. Potiguar University (UNP). Natal, Rio Grande do Norte, Brazil.

2 Nurse. Master degree student in Nursing by the Federal University of Rio Grande do Norte (UFRN). Natal, Rio Grande do Norte, Brazil.

3 Nurse. University Center FACEX. Natal, Rio Grande do Norte, Brazil.

4 Nurse. Ph.D. in Health Science by the Health Science Center (CCS) of the Federal University of Rio Grande do Norte (UFRN). Assistant Professor of UFRN. Natal, Rio Grande do Norte, Brazil.

5 Nurse. Ph.D. in Health Science by the Health Science Center (CCS) of the Federal University of Rio Grande do Norte (UFRN). Natal, Rio Grande do Norte, Brazil.

Contact information:

Belarmino Santos de Sousa Júnior.

Address: Academic nursing. Potiguar University (UNP). Natal, Rio Grande do Norte, Brazil.

Tel: +55 84997071190

Đ sousajunyor@gmail.com

\section{Introduction}

The appearance of pressure ulcers (PU) remains high, despite the technological and scientific advances in the health area. According to a Brazilian study, its incidence varies from 23.1 to $59.5 \%$, especially in patients in intensive care units (ICU) [1]. In this typical scenario for 
the appearance of lesions, the PU constitutes one of the major skin problems that affect critical patients during hospitalization [2]

The ICU is characterized as an appropriate hospital area to care for patients who need medical care and continuous nursing, with particular equipment. They are considered critically hospitalized patients because they usually show changes in one or more vital organs at risk or hemodynamic instability, requiring strict controls. Thus, the ICU is a favorable environment for the emergence of PU [3]. Through studies, it is estimated that in Brazil, the incidence of PUs in ICUs have a percentage of $62.5 \%, 42.6 \%$ in medical clinic units and 39.5\% in surgical units [4].

The PU development occurs when the affected area undergoes cell death, so the soft tissue is compressed between a bony prominence and a hard surface for a prolonged period [5]. Researchers in the area say that currently there are many terms to define it: eschar, decubitus ulcer, pressure ulcer or pressure sore. However, the term "ulcer by pressure" is the more appropriate, since it is the pressure exerted on the tissue and bony prominences about the bed, the most important etiological factors for this lesions [6].

The cause for the emergence of PU happens from two critical etiological determinants, as the duration of the pressure and intensity, added to the tissue tolerance to withstand certain pressure, especially in bony prominences [7]. Among the risk factors that corroborate triggering of PU, there are the intrinsic and extrinsic factors.

Referring to intrinsic factors to the patient age, reduced or absent mobility, altered the level of consciousness (sedation), altered nutritional status, anemia, edema, drug vasoconstriction, vascular disorders, fecal and urinary incontinence can be emphasized. As regards the extrinsic factors, from the environment, the most important are: moisture deficit in hygiene, shear sheet, use of orthopedic instruments, fixed probes and catheters inappropriately, incorrect use of physical/chemical agents, types of mattresses, inadequate seating and lack of decubitus change $[8,9]$.

Places where Pus are most often, there are sacral region, trochanteric, ischial and iliac spines; knees; ankles; calcaneus; elbows; backbone; occipital and ears region. Such lesions cause additional complications such as impaired self-image and self-esteem of patients, pain, suffering, increases the morbidity and mortality rate, increases the length of stay, the cost of patient care and a huge financial burden on health services [9].

Thus, it becomes necessary to know the risk factors for the development of PU, as well as clinical evaluation, and the situation of the skin of patients to take preventive measures. The purpose of those measures is to minimize the incidence of these complications to patients in hospitals [10].

In this sense, the emergence of PU during hospitalization implies a relevant indicator of the quality of care, as stated in MS/GM Decree 529/2013 of the National Patient Safety Program (PNSP). This main objective is to monitor the incidence of PU, and other programs aimed at minimizing them and other health problems [11].

Given the above and seeking to provide subsidies for the implementation of preventive actions in the context of these injuries, it was idealized to conduct this study with the aim of presenting the contributions of scientific productions for the Prevention of Pressure Ulcers in Intensive Care Units.

\section{Methods}

It is a study of an integrative literature review to support the development of preventive actions to critical patients at risk of developing a pressure ulcer.

After delimitation of the topic, the following guiding question was created: "What nursing actions are taken as a preventive measure to the development of Pressure Ulcers in the intensive care unit?". (Figure 1)

Searches for articles were held in April 2016 in electronic databases and libraries Latin American 
Figure 1: Logistics of the integrative literature review. Natal/RN, 2016.

\section{1st Phase: Guiding question}

What nursing actions are taken as a preventive measure to the development of Pressure Ulcers?

$2^{\text {nd }}$ Phase: Data collection
definition of the databases and articles' searching
$3^{\text {rd }}$ Phase: Data evaluation
selected articles after reading the abstracts
$4^{\text {th }}$ and $5^{\text {th }}$ Phase: Data analysis and Elaboration of
the synoptic table
selected articles after Reading in full

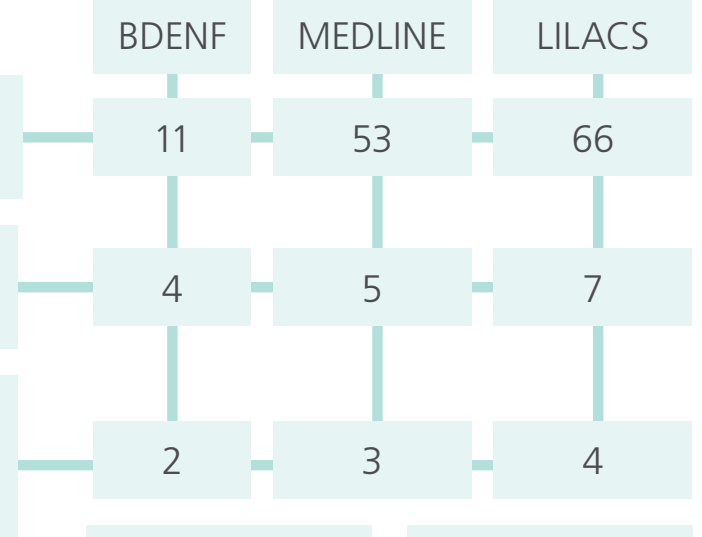

Records

found $=130$

Records selected $=09$

Source: Research data, in 2014.

and Caribbean Health Sciences (LILACS), Nursing Databases (BDENF), International Literature in Health Sciences (MEDLINE). To survey studies relevant to the topic, it was used the following Descriptors in Health Sciences (DeCS): Prevention, "Pressure UIcer", "Nursing" and "Intensive Care Unit".

The following inclusion criteria were adopted: texts published in Portuguese, available online in full in the databases consulted. As exclusion criteria, there were: articles that do not contribute to answering the question proposed in this study.

Data collection occurred through a spreadsheet that included the identification of the article; year of publication; objective; methodology; results; limitations and recommendations of the study. For ease of presentation, analysis and synthesis of data extracted from the articles, they were arranged in synoptic tables. The study took into consideration the ethical aspects, maintaining the authenticity of ideas, concepts and definitions to ensure the authorship of researched articles.

\section{Results}

Nine studies were selected, most of them were publications in 2013 (33\%) and 2014 (22\%). They were distributed in different journals, and magazines of the nursing school USP, Cogitare nursing, and research Magazine: care is fundamental (Online) those that had the highest number of articles, each with two $(22 \%)$ studies. This information is provided in Table 1, below.

Table 1. Characterization of the analyzed articles. Natal/RN, 2016.

\begin{tabular}{|c|c|l|c|c|c|}
\hline N. & Year & Title Of The Article & Type Of Study & Journal & Qualis \\
\hline 1 & 2014 & $\begin{array}{l}\text { Mapping nursing care with NIC for patients at risk of } \\
\text { pressure ulcer }\end{array}$ & $\begin{array}{c}\text { Crossed mapping } \\
\text { Rev. EsC. Enferm. USP. }\end{array}$ A2 \\
\hline 2 & 2014 & $\begin{array}{l}\text { the assessment of the risk of pressure ulcer in ICU and } \\
\text { preventive nursing care }\end{array}$ & $\begin{array}{l}\text { Cross-sectional } \\
\text { Rev. enferm. UERJ. }\end{array}$ & B1 \\
\hline
\end{tabular}




\begin{tabular}{|c|c|c|c|c|c|}
\hline N. & Year & Title Of The Article & Type Of Study & Journal & Qualis \\
\hline 3 & 2013 & Prevention and treatment of pressure ulcers in the daily of intensive care nurses & Descriptive Exploratory & Rev. RENE. & B2 \\
\hline 4 & 2013 & Algorithm prevention and treatment of pressure ulcers & Descriptive Exploratory & Cogitare enferm. & B2 \\
\hline 5 & 2013 & A challenge in nursing care: prevent pressure ulcers on the patient & Literature review & Rev. pesqui. cuid. fundam. (Online). & B2 \\
\hline 6 & 2012 & Actions of nurses in care management for the prevention of pressure ulcers in intensive care unit & Descriptive Exploratory & Rev. pesqui. cuid. fundam. (Online). & B2 \\
\hline 7 & 2009 & Analysis of prevention and treatment of pressure ulcers proposed by nurses & Literature review & Rev. Esc. Enferm. USP. & A2 \\
\hline 9 & 2006 & $\begin{array}{l}\text { Applying recommendations of the Braden Scale and preventing pressure ulcers - evidence of } \\
\text { nursing care }\end{array}$ & Quantitative & Rev. bras. enferm. & A2 \\
\hline
\end{tabular}

Source: Research data, 2016.

There were preventive nursing actions found aimed at the development of $\mathrm{PU}$ in ICU, and the difficulties and limitations in its implementation. To facilitate the presentation, information is shown in Table 2 below.

The nine articles described the UP prevention actions, some similarly as the synoptic table (Table 2). The data synthesis in the synoptic tables sup- ported the preparation of the proposed definition of preventive actions in the development of pressure ulcers (Table 3).

Table 2. Prevention actions for PU described in the analyzed articles in the integrative literature review. Natal/RN, 2016.

\begin{tabular}{|c|c|c|}
\hline N. & Preventive actions & Dificulties/Limitations \\
\hline 1 & $\begin{array}{l}\text { To perform changing positions; to keep pyramidal mattress; implement clinical protocol prevention; to protect } \\
\text { the skin and bony prominences; to keep the perineum clean and dry; to moisturize the skin; to daily inspect the } \\
\text { skin in search of hyperemia or ischemic points [12]. }\end{array}$ & $\begin{array}{l}\text { Lack of NIC interventions aimed directly at the Nursing } \\
\text { Diagnosis (ND) Ulcer Risk by pressure. }\end{array}$ \\
\hline 2 & $\begin{array}{l}\text { To change decubitus 2/2h; pyramidal mattress; cleaning the bed; cleaning of the patient; using cushions; skin } \\
\text { hydration; application of the Braden Scale (BS); Identification of risk factors [13]. }\end{array}$ & $\begin{array}{l}\text { Applicability of actions during the night shift; lack of adherence } \\
\text { to the BS by nurses; lack of nursing prescriptions regarding } \\
\text { prevention; actions not carried out according to the BS. }\end{array}$ \\
\hline 3 & $\begin{array}{l}\text { Comfort massage after-bath with moisturizer; changing positions } 2 / 2 \mathrm{~h} \text {; mattress egg crate; keeping sheets } \\
\text { stretched [14]. }\end{array}$ & $\begin{array}{l}\text { Lack of human resources and material; lack of standardization } \\
\text { of the actions. }\end{array}$ \\
\hline
\end{tabular}


4 To assess the risk in the first 48 hours of admission, according to the BS; to keep clean and dry skin; to treat incontinence; to avoid contact with plastic surfaces; to maintain body temperature between 35.5 and 37; repositioning the patient as decubitus change scheme (clock) 2/2 hours; to request evaluation of physiotherapy when available; to monitor the nutritional status through laboratory tests; to assess nutritional impairment; to use mobile sheets to mobilize the patient; to avoid massages in hyperemia areas with reduced sensitivity; to keep head elevated 3; to avoid gel or padded boots; to avoid use of foam rings; to apply pads under bone prominences [15].

5 To identify individuals at risk and factors that predispose them to the risk; to maintain and improve tissue tolerance to pressure; protecting the tissues against the adverse effects of mechanical forces (pressure, friction, and shear); to reduce the incidence of these ulcers through educational programs [16]

6 Guidance to nursing technicians; management of care; changing positions; daily physical examination of the skin; skin hydration; use of cushions; nutritional support; use of pyramidal mattress; comfort massage [17].

7 Risk level assessment through prediction scales; protocol preparation to prevent PU; to provide polyurethane mattress (egg box); to identify risk factors individually and to direct the preventive treatment; changing position $2 / 2 \mathrm{~h}$; to protect bony projections, especially calcaneal region; to register changes in the skin; early treatment of the skin; daily checking of vulnerable areas; providing nutritional support; treating incontinence; documen interventions and results obtained; to protect/prevent complications by external mechanical forces; to create and provide an educational program for at-risk patients in developing PU and their caregivers [18].

8 To assess the daily risk in patients with special attention to bony prominences; to correctly position the client in bed; to keep the skin clean; to avoid force and friction; to reduce humidity, exposure to cold; to moisturize the skin, avoiding massage bony prominences; to reduce skin contact with moisture for urinary incontinence, fecal or draining wound, fistula, stoma or perspiration; to avoid shear and friction; pay attention to proper nutritional intake; to develop decubitus scaling $2 / 2 \mathrm{~h}$ or according to their needs; to protect trochanteric, religious and calcaneal regions; to maintain high head $3^{\circ}$ according to the patient's clinical condition; to avoid the use of ringshaped pads [19].

9 To maintain personal hygiene; to apply moisturizer; to apply ointment in the genital area; to keep dry skin; performing comfort massage; to keep clean and stretched sheets; to use mobile table; changing diapers every physiological elimination; decubitus change every 2 hours; to inspect the skin twice a day; to use transparent dressings; to raise heels with cushions; position properly/avoid slipping; pad bony prominences; use pillow and/ or cushion for repositioning; using mattress egg crate; keeping head to $3^{\circ}$ degrees; maintaining prescribed nutritional support [2].
Vol. 9 No. 183 oi: $10.3823 / 2054$

Lack of resources; accommodation for health professionals; the need for investments related to public health policies, aimed at training to predict, provide and maintain the availability of necessary staff and equipment to the reduction and/or elimination of these ulcers on the patient.

Lack of human resources; work overload due to the clinical instability of patients; high absenteeism rate.

Lack of institutionalization of care practices possibly due to the knowledge of professional interventions in the prevention.

Constant updating of the professional nurse concerning the issue, because he is who develops the patient prevention actions with the risk of developing such lesions.

Encouraging the adoption of preventive measures other hospitals.

Source: Research data, 216 
Table 3. Definition of the preventive actions in the development $f$ pressure ulcers. Natal/RN, 2016.

\section{Preventive actions}

Management

Care Management;

Protocol elaboration for prevention of PU;

Development of graphic clock for decubitus change signaling;

To evaluate and identify patients at risk during the first 48 hours of admission by a prediction range, the most used Braden Scale (BS), and then evaluated daily;

To identify the factors that predispose to risk individually; Implementation of clinical protocol of prevention;

Requesting support for physiotherapy and nutrition;

Documenting interventions and results obtained.

Education

Orientation and training of nursing technicians;

Creating and providing an educational program for patients at risk of developing PU and their caregivers;

Establishing educational programs and including them as a preventive method.

\section{Care}

Performing decubitus changes 2/2h;

Correctly position the patient in bed;

Inspecting daily skin;

Keeping skin moisturized (avoid rubbing bony prominences in hyperemia areas with reduced sensitivity);

Maintaining hygiene of the patient and the bed;

Keeping clean, dry and taut sheets (avoid contact with the patient's skin with plastic surfaces);

Always use mobile sheets to mobilize the patient;

Apply barrier cream on genital region and contact with acidic physiological substances;

Monitoring the nutritional status through laboratory tests;

Keeping polyurethane mattress (pyramidal/egg box);

Keeping perineum clean and dry;

Avoiding exposure to cold;

Using cushions to relieve areas of friction and raising the calcaneal region (do not use foam cushions shaped ring);

\section{Preventive actions}

Care

Treating incontinence;

Maintaining body temperature between 35.5 and 37;

Keeping head elevated $30^{\circ}$ according to the clinical condition of the patient;

Avoid gel or padded boots;

To protect the tissues against the adverse effects of mechanical forces (pressure, friction, and shear);

Changing diapers every physiological elimination;

Source: Research data

\section{Discussion}

The analysis of the articles allowed to answer the main question of the study and from this, to base the definition of preventive actions in the development of these lesions. The few studies show that nursing still needs to deepen in clinical practice to contribute to other scientific studies. The synthesis of preventive actions from the study was divided into three areas: management, education and care, shown in the Synoptic Table 3.

The administrative tasks of nursing care are the relationship between the care and management axes that make up the work of nurses in the numerous action scenarios. The care management term has been used to elucidate mainly the activities of nurses aiming at better results in clinical practice in health services and the completion of the planning of the actions of nursing care $[17,21]$.

Thus, care management actions focused on PU prevention are crucial for the whole process to prevent from happening. It is understood that the volume of activities and the pace of work are challenges that nurses professionals face mainly in the assistance units to critically ill patients. However, the implementation and use of risk prediction scales, such as the Braden scale, and the development of prevention protocols become important strategies that can facilitate guiding the nursing teamwork [18, 22, 23]. This management axis includes actions that focus 
on the development and implementation of tools that assist in individualized care planning geared to the needs of each guiding the prevention of such injuries to patients at risk of developing them.

There are several risk prediction scales helping the nursing professionals in focused management to detect and assess the risk that the patient has to develop PU. Studies point to the Braden Scale (BS) as the most used and most studied in Brazil. This, when used in the ICU, should be applied at the time of patient admission in the sector and repeated every 48 hours [23, 24, 25].

About the educational activity as PU preventive methods in critically ill patients involving nursing staff and their caregivers also involves in training the applicability of scales and protocols. The performance of a periodic assessment of organizational performance in the prevention of PU and provide feedback of that same information to all the interested ones can support such educational measures $[17,26]$. The orientation and training through educational programs related to the prevention of such injuries with the nursing professionals strengthen protocols of proposals as well as their applicability in the hospital.

It was observed the Synoptic Table 3, as regards the care practices, recommendations of studies focusing on the PU prevention actions. The care nursing interventions of preventive character that should address aspects are highlighted such as daily observation of the skin care skin integrity, position change and correct positioning, use of moisturizing and barrier creams, use of devices for treatment incontinence, care of the hygiene of the patient and the bed, nutrition rich in vitamins and proteins, maintain proper mattress, avoid excessive cold, keep clean sheets and drawn, keep head elevated $30^{\circ}$ degrees, changing diapers and sheets every physiological disposal and use cushions to relieve friction areas.

\section{Conclusion}

The review of scientific production contributed to show actions aimed at prevention of Pressure Ulcers in the Intensive Care Unit and the classification of these measures in management, educational and welfare.

Management activities corroborate the planning, implementation, and evaluation of preventive actions such injuries directed to critical patients, also, contributing to the development of prevention protocols and the applicability of risk prediction scales as tools that help the preventive process. About educational activities, it can be considered them crucial to the whole process, as this axis gives grants to management and the feasibility of preventive actions. And caring for patients, technical implementing measures are listed to minimize the occurrence of PU to ICU patients.

Thus, it is necessary to expand and develop studies aimed at preventing injuries that may contribute to the clinical practice of professional nursing, thus making assistance based on scientific evidence focused on patient safety.

\section{References}

1. Rogenski NMB, Kurcgant P. The incidence of pressure ulcers after the implementation of a prevention protocol. Rev LatinoAm Enfermagem [Internet]. 2012 [cited 2015 Apr 22]; 20(2):3339. Available from: http://www.scielo.br/scielo.php?script=sci ar ttext\&pid=S010411692012000200016\&lng=en\&nrm=iso

2. Alves AG, Borges JW, Brito MA. Avaliação do risco para úlcera por pressão em unidades de terapia intensiva: uma revisão integrativa. J Res Fundam Care [Internet]. 2014[cited 2016 Apr 02]; 6(2):793-804. Available from: http://www.seer.unirio.br/ index.php/cuidadofundamental/article/view/3004/pdf 1287

3. Dantas ALM, Ferreira PC, Diniz KD, Medeiros ABA, Lira ALBC. Prática do enfermeiro intensivista no tratamento de úlceras por pressão. Rev. Pesquisa Cuidado é Fundamental Online [internet]. 2014. [cited 2015 Dec 20]. DOI: http://dx.doi.org/10.9789/21755361.2014.v6i2.716-724

4. Bavaresco T, Medeiros RH, Lucena AF. Implantação da escala de Braden em uma Unidade de Terapia Intensiva de um hospital universitário. Revista Gaúcha de Enfermagem Online. 2011. [cited 2016 Jan 20]. Available from: http://dx.doi.org/10.1590/ S1983-14472011000400010 
5. Freire IM. Assistência de enfermagem a portador de úlceras por pressão, tratado com hidrofibra com prata iônica. Porto Alegre: Congresso Brasileiro de Estomaterapia; 2011.

6. Lima AC, Guerra DM. Avaliação do custo do tratamento de úlceras por pressão em pessoas hospitalizados usando curativos industrializados. Cien Saúde Coletiva [Internet]. 2011 [cited 2015 Jan 28];6(1):267-77. Available from: http://www.scielo.br/scielo. php?script=sci arttext\&pid=S141381232011000100029\&lng=e $\underline{n} \& n r m=i s o$

7. Silva DP, Barbosa MH, Araujo DF, Oliveira LP, Melo AF. Úlcera por pressão: avaliação de fatores de risco em pacientes internados em um hospital universitário. Rev Eletrônica Enferm [Internet]. 2011 [cited 2014 Dec 14];13(1):118-23. Available from: http:// www.fen.ufg.br/revista/v13/n1/v13n1a13.htm

8. Mattia AL, Barbosa MH, Borgato MA, Silva MOR, Freitas Filho SRA. Úlcera por pressão em UTI: fatores de risco e medidas de prevenção. Rev. Saúde Coletiva. 2010. [cited 2015 Jan 28]; v. 07, n. 46, p. 296-299. Available from: http://www.redalyc.org/ articulo.oa?id=84215678003

9. Silva MLN, Caminha RTÓ, Oliveira SHS, Diniz ERS, Oliveira JL, Neves VSN. Úlcera por pressão em unidade de terapia intensiva: análise da incidência e lesões instaladas. Rev Rene. 2013[cited 2016 Apr 02];14(5):938-44. Available from: http://www. revistarene.ufc.br/revista/index.php/revista/article/view/1341

10. Mattia AL, Barbosa MH, Borgato MA, Silva MOR, Freitas Filho SRA. Úlcera por pressão em UTI: fatores de risco e medidas de prevenção. Rev. Saúde Coletiva. 2010. [cited 2015 Jan 28]; v. 07, n. 46, p. 296-299. Available from: http://www.redalyc.org/ articulo.oa?id=84215678003

11. Brasil. Portaria MS/GM 529, de 1 de abril de 2013. Programa Nacional de Segurança do Paciente (PNSP). Brasília; 2013

12. Pereira AGS, Santos $C T$, Menegon DB, Mello BS, Azambuja F, Lucena AF. Mapeamento de cuidados de enfermagem com a NIC para pacientes em risco de úlcera por pressão. Rev. esc. enferm. USP [Internet]. 2014. [cited 2016 Apr 17] ; 48( 3 ): 454-461. Available from: http://www.scielo.br/scielo.php?script=sci artte xt\&pid=S008062342014000300454\&lng=en

13. Barbosa TP, Beccaria LM, Poletti NAA. Avaliação do risco de úlcera por pressão em UTI e assistência preventiva de enfermagem. Rev enferm UERJ [Internet]. 2014. [cited 2016 May 23]; 22(3):353-8. Available from: http://www.e-publicacoes. uerj.br/index.php/enfermagemuerj/article/view/13724/10493

14. Rolim JA, Vasconcelos JDMB, Caliri MHL, \& Santos IBDC. Prevenção e tratamento de úlceras por pressão no cotidiano de enfermeiros intensivistas. Revista da Rede de Enfermagem do Nordeste-Rev Rene [Internet]. 2013. [cited 2016 Jan 28];14(1). Available From: http://www.revistarene.ufc.br/revista/index. php/revista/article/viewFile/336/pdf
15. Pott FS, Ribas JD, da Silva OBM, de Souza TS, Danski MTR, \& Marineli MJ. Algoritmo de prevenção e tratamento de úlcera por pressão. Cogitare Enfermagem [Internet]. 2013. [cited 2016 Jan 25]; 18(2). Available from: http://revistas.ufpr.br/cogitare/ article/view/26085

16. Brandão EDS, Mandelbaum MHS, \& Santos ID. Um desafio no cuidado em enfermagem: prevenir úlceras por pressão no cliente. Rev. pesqui. cuid. fundam. (Online) [Internet]. 2013. [cited 2016 Feb 09]; 5(1), 3221-3228. Available from: http:// www.seer.unirio.br/index.php/cuidadofundamental/article/ viewFile/1956/pdf 677

17. Stein EA, Santos JLGD, Pestana AL, Guerra ST, Prochnow AG, \& Erdmann AL. Ações dos enfermeiros na gerência do cuidado para prevenção de úlceras por pressão em unidade de terapia intensiva. Rev. pesqui. cuid. fundam.(Online) [Internet]. 2012. [cited 2016 May 02]; 4(3), 2605-2612. Available fron: http:// www.seer.unirio.br/index.php/cuidadofundamental/article/ view/1606/pdf 599

18. Medeiros ABF, Lopes CHAF, \& Jorge MSB. Análise da prevenção e tratamento das úlceras por pressão propostos por enfermeiros. Rev Esc Enferm USP [Internet]. 2009. [cited 2016 Jan 20]; 43(1),223-228. Available fron: https://dx.doi. org/10.1590/S008062342009000100029

19. Rodrigues MM, Souza MDS, \& Silva JL. Sistematização da assistência de enfermagem na prevenção da lesão tecidual por pressão. Cogitare enferm [Internet]. 2008. [cited 2015 Dec 20]; 13(4), 566-576. Available from: http://revistas.ufpr.br/ cogitare/article/view/13117/8875

20. Sousa CAD, Santos ID, \& Silva LDD. Aplicando recomendações da Escala de Braden e prevenindo úlceras por pressão-evidências do cuidar em enfermagem. Rev bras enferm [Internet]. 2006. [cited 2016 Feb 22]; 59(3), 279-84. Available from: http://dx.doi. org/10.1590/S0034-71672006000300006

21. Santos JLG, Pestana AL, Guerrero $P$, Meirelles BSH, Erdmann AL. Práticas de enfermeiros na gerência do cuidado em enfermagem e saúde: revisão integrativa. Rev. bras. enferm. [Internet]. 2013. [cited 2016 Apr 12] ;66(2):257-263. Available from: http:// www.scielo.br/scielo.php?script=sci_arttext \&pid=S003471672013000200016\&lng=en

22. Medeiros ABF, Lopes $C$, Jorge MSB. Análise da prevenção e tratamento das úlceras por pressão propostos por enfermeiros. Rev. Esc. Enferm. USP [Internet]. 2009. [cited 2016 My 17];43(1):223-28. Available from: http://www.scielo.br/scielo. php?script=sci arttext\&pid=S0080-62342009000100029 
23. Araújo TM, Araújo MFM, Caetano JÁ. Comparação de escalas de avaliação de risco para úlcera por pressão em pacientes em estado crítico. Acta Paul Enfermagem [Internet]. 2011. [cited 2016 Apr 05];24(5):695-700. Available from: http://www. scielo.br/scielo.php?pid=S010321002011000500016\&script $=$ s ci abstract\&tlng $=p t$

24. Costa IG, Caliri MHL. Validade preditiva da escala de Braden para pacientes de terapia intensiva. Rev. Acta Paul Enfermagem [Internet]. 2011. [cited 2015 Dec 19] ;24(6):772-777. Available from: http://www.scielo.br/scielo.php?script=sci arttext\&pid $=$ S0103-21002011000600007

25. Matos LS, Duarte NLV, Minetto RC. Incidência e prevalência de úlcera por pressão no CTI de um Hospital Público do DF. Rev. Eletrônica Enfermagem [Internet]. 2010. [cited 2016 Apr 01 ];12(4):719-726. Available from: https://www.fen.ufg.br/fen revista/v12/n4/pdf/v12n4a18.pdf

26. National Pressure Ulcer Advisory Panel, European Pressure Ulcer Advisory Panel and Pan Pacific Pressure Injury Alliance. Prevention and Treatment of Pressure Ulcers: Quick Reference Guide. Emily Haesler (Ed.). Cambridge Media: Osborne Park, Western Australia [Internet]. 2015. [cited 2016 May 22]. Available from: http://www.epuap.org/guidelines-2014/Portuguese-Quick\%20 Reference\%20Guide-Jan2015.pdf

Publish in International Archives of Medicine

International Archives of Medicine is an open access journal publishing articles encompassing all aspects of medical science and clinical practice. IAM is considered a megajournal with independent sections on all areas of medicine. IAM is a really international journal with authors and board members from all around the world. The journal is widely indexed and classified Q1 in category Medicine. 